\title{
Measuring the consumption value of higher education
}

\author{
Annette Alstadsæter* \\ Statistics Norway ${ }^{\dagger}$ \\ NHH Discussion Paper SAM 04/2004
}

\begin{abstract}
The consumption value of education is an important, but rather ignored factor behind the individual's educational choice. This paper suggests a method for measuring the consumption value of education in a compensating differentials framework when the ability bias is corrected for. As an example, the willingness to pay for the consumption value of attending teacher's college during the 1960's is estimated on unique Norwegian panel data. The ex-ante price of the consumption value of teacher's college is estimated to be $38 \%$ of the present value of the individual's potential lifetime income. The ex-post price of this consumption value is for the same individuals estimated to be about $46 \%$ of the present value of the potential lifetime income.
\end{abstract}

JEL-classifications: J24; J31; J33; I21; H89.

*Acknowledgements: Jarle Møen provided me with the idea in the first place, and I thank him and my advisor Professor Agnar Sandmo for interesting discussions and help along the way. Professor Kjell G. Salvanes, Knut R. Wangen, Erik Sørensen, and seminar participants at the Norwegian School of Economics and Business Administration provided most appreciated comments. Grant 140731/510 from the Research Council of Norway is gratefully acknowledged.

${ }^{\dagger}$ Research Department, P.b. 8131 Dep., N-0033 Oslo. E-mail: aal@ssb.no 


\section{Introduction.}

Higher education can be viewed both as a consumption good for which the individual is willing to pay, and as an investment alternative that yields higher wages later in life. The factors determining the individual's educational choice can be divided into three groups: preferences, returns, and costs. The costs of attending higher education are effort, time and money, both direct monetary outlays and forgone labor income ${ }^{1}$. The return to higher education comes both as pecuniary and non-pecuniary returns. As higher education increases the skill level, and thus also the productivity of the individual, he is paid a higher wage in the labor market. Also, higher skilled individuals qualify for different types of jobs than lower skilled individuals. Highskilled jobs often offer various fringe benefits, which are not paid as money, but which are all equivalent to a wage increase. Fringe benefits ${ }^{2}$ and the wage premium constitute the pecuniary return to higher education. The individual specific nonpecuniary return to higher education is the intrinsic or the consumption value of education, which is defined in section 3 .

This paper suggests a method for measuring the consumption value of education in a compensating differentials framework when the ability bias is corrected for. The identification strategy is to compare two individuals who attended teacher's college and business school respectively in Norway during the 1960's. In this period these two types of education required the same minimum average grade level from high school for admittance, but they generated very different wage returns. The wage return from attending business school in this period is used as a benchmark for the potential wage return of the teacher's college graduates. Using the Norwegian 1970 census, cross section wage profiles are estimated for those business school and teacher's college graduates with different levels of working experience. These wage profiles are interpreted as the expected future wages of the individuals attending business school and teacher's college during the 1960's. The ex-ante price of the consumption value of teacher's college is estimated to be $38 \%$ of the present value of the individual's potential lifetime income. Using unique Norwegian panel data the actual wage profiles for the individuals acquiring their education during the 1960's are estimated. The ex-post price of this consumption value of teacher's college turned

\footnotetext{
${ }^{1}$ Costs are disregarded in the following analysis.

${ }^{2}$ Fringe benefits are here defined to be benefits with a clear monetary equivalent, such as a company car, free newspaper subscriptions, and a company health insurance.
} 
out to be about $46 \%$ of the present value of their potential lifetime income.

The goal of the paper is not to find the exact value of the willingness to pay for the consumption value of education, but rather to establish as a fact that the consumption value of education does exist and that it is an important factor behind the individual's educational choice. As shown by the example, many individuals are willing to give up substantial future wage returns in order to acquire the educational type of their choice. Therefore, the consumption value of education should not be ignored when modeling the individual's educational choice and estimating the return to education.

The paper is organized as follows: Section 2 gives an historical overview of the debate on the return to education, and section 3 discusses and defines the concept of consumption value of education. The estimation of the monetary value of the consumption value of teacher's college relative to business school is conducted in section 4. Section 5 concludes.

\section{Higher education: Investment or consumption?}

Prior to the human capital revolution in the 1960's, education was considered to be a consumption good. One shortcoming of this framework was that it ignored the fact that pursuing education actually increases the productivity of the individual and his wages in the next period. Schultz ${ }^{3}$ (1960) and Becker (1964) introduced the theory of human capital, where education is an investment that increases the individual's wage in the next period. The individual acquires education until the present value of the expected marginal wage return equals the marginal return of other investment alternatives. The cost of the investment is the sum of the direct costs, such as tuition fees, books and other expenses, and forgone labor income. This theory was highly controversial at the time, since education was considered to be a cultural good. Schultz (1960) stated that "it is held by many to be degrading to man and morally wrong to look upon his education as a way of creating capital. ...For them education is basically cultural and not economic in its purpose, because education serves to develop individuals to become responsible citizens. ...My reply to those who believe

\footnotetext{
3"I propose to treat education as an investment in man and to treat its consequences as a form of capital. Since education becomes a part of the person receiving it, I shall refer to it as human capital." Shultz (1960).
} 
thus is that an analysis that treats education as one of the activities that may add to the stock of human capital in no way denies the validity of their position... Some kind of education may improve the capabilities of a people as they work and manage their affairs, and these improvements may increase the national income."

Mincer $(1974)^{4}$ developed the framework which is still the most frequently used in the empirical estimation of the wage return to education. A simplifying assumption in this model is that the wage return to job experience and the wage return to education can be estimated separately. In his model, the log of the individual's earnings, $Y$, in a period can be decomposed into an additive function of a linear education term and a quadric experience term:

$$
\ln Y=\beta_{1}+\beta_{2} E+\beta_{3} X+\beta_{4} X^{2}+\epsilon
$$

where $E$ is the length of the completed education in years, $X$ represents the number of years of work experience ${ }^{5}$ after leaving school, and $\epsilon$ is the residual. The parameter $\beta_{2}$ is then the rate of return to an additional year of education. This marginal return to education is assumed to be independent of both type and level of education. $\beta_{3}$ represents the return to experience, which is expected to be concave, and $\beta_{4}$ estimates the extent of this concavity. But there are problems with this approach. It assumes that education increases the individual's wage, but it could also be that this is a result of individuals with high innate income potential choosing to acquire higher education, such that there is an ability bias in the sample. Also, the relationship between occupational choice, earnings, and job attributes is simultaneously determined; the reward structure determines the educational choice, and the educational choice determines the reward structure. Thus the amount of schooling included in the wage equation is not exogenous, and a simultaneity problem exists. Another problem is that there is heterogeneity in the wage return to human capital investments. Willis and Rosen (1979) claim that this induces the individual to choose the type of education for which he has a comparative advantage given his innate abilities. The analysis in this paper concentrates on solving the selection problem.

Increasingly sophisticated econometric methods have been developed to correct for the above described estimation problems, and this has been the focal point in

\footnotetext{
${ }^{4}$ See Chiswick (2003) for a retrospective discussion of the importance of Mincer's contribution.

${ }^{5}$ In the absence of direct information on work experience Mincer suggested to use "potential experience", which is the individual's age minus his school starting age minus years in school.
} 
the empirical literature over the last twenty years. ${ }^{6}$ The existence of other motives for the individual's educational choice besides higher future wages has been more or less ignored. Instead of analyzing what motivates the individual's educational choice, the effort has been concentrated on analyzing the most easily measurable outcome of this choice, namely the effect on wages.

But economics is the theory of choice, and it deals with the satisfaction of human desires through choice of actions. Human desires are satisfied by human interaction and through economic activity, which is the exchange of goods and services. Plato defined three types of desires; desire for wisdom and knowledge, for honor, fame, and power, and the appetitive desires, which are usually satisfied through spending money. The satisfaction of these desires is motivated and accompanied by pleasure, which is necessary up to a point and harmful when pursued in excess. Marshall distinguished between wants and activities. Wants are satisfied by consumption of services and goods, while activities either contribute to the production of goods and services or are pleasurable in themselves.

Adam Smith was the first to formulate the idea of monetary and non-monetary compensations of a job, an idea later formalized in the compensating differentials literature: "The five following are the principal circumstances which, so far as I have been able to observe, make up for a small pecuniary gain in some employments, and counterbalance a great one in others: first, the agreeableness or disagreeableness of the employments themselves; secondly, the easiness and cheapness, or the difficulty and expense of learning them; thirdly, the constancy or inconstancy of employment in them; fourthly, the small or great trust which must be reposed in those who exercise them; and fifthly, the probability or improbability of success in them. ...Honour makes a great part of the reward of all honorable professions. In point of pecuniary gain, all things considered, they are generally under-recompensed. ...Disgrace has the contrary effect." ${ }^{7}$ Later Marshall (1920) stated that "the true reward which an occupation offers the labourer has to be calculated by deducting the money value of all disadvantages from that of all its advantages".

The fact that activities can be pleasurable in themselves and help satisfy certain desires has for a long time been widely ignored in the economic literature. There are a few exceptions, though. Lazaer (1977) finds in his sample of US males that lower levels of higher education are considered a consumption bad by the individual,

\footnotetext{
${ }^{6}$ See Card (1999) for an extensive literature overview of this field.

${ }^{7}$ The Wealth of Nations, Book 1, Ch. 10, Part1.
} 
while MA's and PhD's are considered to be consumption goods ${ }^{8}$. Oosterbeek and van Ophem (2000) allow the individual to have immediate utility from schooling, and they maximize lifetime utility instead of the usual lifetime income approach. They find that the young Dutch individuals in their sample invest too much in education compared with what is optimal from the human capital theory, and they conclude that the consumption motives with regard to schooling are indeed important ${ }^{9}$. Kodde and Ritzen (1984) combine the human capital model and the consumption model and find that the individual demands more education than in the pure human capital model. This is due to the direct utility gain he experiences through the consumption of education. Oosterbeek and Webbink (1995) find that the integrated model where education is both an investment alternative and a consumption good is the best to explain the educational choices of the young individuals, and that both the consumption motive and the investment motive matter. The shortcomings of the pure human capital model in explaining the individuals' educational choices are also pointed out by Oreopoulos (2003).

More work has been done on identifying different non-pecuniary returns to a particular job, such as pleasant working conditions or status. Examples are Antos and Rosen (1975), Ward and Sloane (2000), and Scott (2001), who all apply the compensating differentials framework described in Rosen (1986).

Stern (1999) considers a sample of postdoctoral biologists who decide where to start working, and who are offered jobs with different job characteristics. The result suggests a strong negative relationship between wages and the opportunity to engage in scientific activity; the biologists have to pay, in forgone wages, to be able to do scientific work. Firms who allow their employees to publish papers based on their results from the job pay on average $25 \%$ lower wages than the firms who do not allow their employees to engage in academic activity. This line of reason is also followed by Klette and Møen (2002), who state that academics pay a considerable price for their academic joy, measured in forgone labor income by not working in the private sector.

The literature also mostly ignores that different types of education generate dif-

\footnotetext{
${ }^{8}$ Gullason (1989) also finds a positive "consumption value" to schooling for US males, where most of this value consisted of avoiding being drafted for the Vietnam war as long as the person was in school.

${ }^{9}$ This idea was already promoted by Schaafsma (1976).
} 
ferent rates of wage return. Education is assumed to be a homogenous good that generates an annual rate of return. One exception is Keane and Wolpin (1997). In a dynamic structural model they consider self-selection in three heterogenic dimensions: schooling, work, and occupational choice, and they find that most of the variance in lifetime utility is explained by inequality in skill endowment. Aakvik et al. (2003) also find on rich Norwegian panel data that the wage return to education is heterogenous among individuals.

Although the existence of non-pecuniary returns to education is acknowledged in the literature, they are seldom included in the formal analysis. The non-pecuniary returns to education are mostly only mentioned anecdotally, and a proper definition of the consumption value of education is to my knowledge missing in the literature. The discussion below aims at correcting for this.

\section{Non-pecuniary returns to higher education.}

Acquiring higher education has many effects; some serve as incentives for the individual at the time of the educational choice, whereas others are by-products of the educational process. The non-pecuniary return to higher education can from the individual's point of view be divided into two groups; intended and unintended non-pecuniary benefits. The consumption value of higher education is the intended non-pecuniary returns to education; these are the factors the individual is aware of at the time of the educational choice. But there are other non-pecuniary returns to higher education, of which the individual may not be aware at the time of his educational choice. These are the unintended non-pecuniary returns to higher education.

\subsection{The consumption value of higher education.}

Substantial non-pecuniary advantages and returns to education exist, both during the educational process and after its completion. Duncan (1976) defined the consumption benefits of a job as the positive flow of satisfaction provided by the work situation. This may be enjoyment, interest, challenge, and social relationships, which are all subjective relations of individuals to the job situation. Higher education enables the individual to choose from a broader specter of jobs that are mostly considered more interesting and more challenging (Weisbrod, 1962). Higher education 
makes the individual more flexible in the type of job he is able to perform, as well as in where to perform it, which provides insurance against unemployment (Bishop, 1994). This flexibility varies between different types of education, and individuals who prefer to live in a particular area or who prefer the option of part-time work will choose educational types that lead to jobs with these attributes.

Different types of education differ in how much effort is required from the individual to complete the education. The effort level required in the jobs available after completed education also varies. Low effort input and thus much leisure are qualities valued by many individuals. There is also a non-dismissable increase in social status from completing a higher education. Dolton et al. (1989) find that among arts and social science graduates it seems like occupational status plays an important role in the educational choice.

The consumption value of education while acquiring it consists among other things of the joy of learning new things, meeting new people, moving to a new city, and participating in campus and student activities, in addition to the increased status in the society that often comes from being a student of particular fields ${ }^{10}$. Nerdrum (1999) discusses this in detail and states that "some people choose to become students mostly to be able to take part in such a way of life. Their aim is principally directed towards immediate consumption, and they consider the other effects, like positive monetary returns, as pure positive by-products".

I summarize all these non-pecuniary returns to education as the consumption value of education.

Classification difficulties. Not all non-pecuniary returns to education are straightforward to classify. For instance, Nerdrum (1999) states that memberships in clubs and organizations during their time as a student provide the individuals with a network of people spread over the world, both for professional and private purposes, which often prove to be extremely valuable. If having this network provides the individual with an intrinsic joy, it should be counted as a part of the consumption value of education. But if this network furthers his career, it is a kind of investment during the education that yields a future monetary return, and it should not be regarded

\footnotetext{
${ }^{10}$ Scitovsky (1976) states that as countries get richer and the individuals have more leisure, they need satisfaction to avoid boredom. He also states that education is one such stimulus that increases satisfaction both during and after the educational period if chosen correctly.
} 
as a consumption value of education.

The fact that one educational type requires less effort both during the educational process as well as in the future jobs is above defined as a consumption value, since the individual enjoys having more leisure. But one could also claim that this educational type has lower investment costs, measured in effort.

\subsection{Unintended non-pecuniary returns to education.}

When making his educational choice, the individual maximizes his ex-ante preferences, and thus the consumption value of education ought to be measured at this point in time. The educational process might change his preferences, such that his ex-post preferences differ from his ex-ante preferences, along with his ex-post valuation of the consumption value of education. These changes in preferences are ex-ante unforeseen. They do not serve as a motivation behind the individual's educational choice, and should thus not be included in the ex-ante consumption value of education. See Sandmo (1983) for a discussion of ex-ante vs. ex-post welfare evaluations.

Unintended individual returns. The human capital theory allows for the existence of consumption effects of education, but they are only mentioned anecdotally and consist of factors such as learning to appreciate opera and reading Goethe in the original language ${ }^{11}$. These changes in preferences are unintended, since they are results of influence on the individual during the time of his education. They are not the result of a conscious choice, since he did not treasure these things at the time of the educational choice. Individuals make their educational choice in order to maximize their utility according to their ex-ante preferences. Thus this effect is not part of the consumption value of education as defined in this paper.

If interpreted within a framework similar to the "Rational Addiction" 12 approach of Becker and Murphy (1988), or more generally the "Extended Preference" approach of Becker (1996), the conclusion is the opposite of the one above. These approaches generalize the usual discounted utility model, by letting the instantaneous utility in any given period be a function of past consumption experiences. In the intertemporal optimization problem, the rational consumer takes into account that even if he

\footnotetext{
${ }^{11}$ See for instance Judd (2001) and Nerdrum (1999).

${ }^{12}$ See Wangen (2003) for a discussion of this.
} 
prefers rock music to classical music in the present period - according to today's instantaneous utility function - he foresees that the educational process changes his future instantaneous utility functions in a way that will make him prefer classical music.

Preferences: Shifts and history dependence. In most economic models individuals' preferences are assumed to be exogenously given and constant over time, when they are in fact influenced and shaped by the surroundings. New information, learning, experience, innovation, and human interactions affect the individual and might induce a shift in his preferences over time. If the individuals were to make their educational choices at the age of five, we would have nations of firemen! This section discusses these preference shifts in more detail.

Croix (2001) claims that intergenerational spillover has taste externalities, as when fear of insects or career aspirations are transmitted from parents to children. Hægeland et al. (1999) find that parental educational level has a positive effect on the length of the education the children acquire. Preferences are also transmitted through the habit formation effect, which reflects the effects of past decisions on the perception of current outcomes. Different aspects of the consumption value of higher education can be subject to history dependence, as stated by Acemoglu (1995). New generations learn from the older generations and to some extent inherit established value judgements and attitudes. For instance, what is perceived to give social status and prestige changes over time as the external factors such as political regime, religion, and economics change ${ }^{13}$. This affects who chooses the different occupations and thus also the distribution of talent in the society.

Bowles (1972) argues that "there is considerable evidence that rich, high status parents place a larger value on the non-pecuniary aspects of work and a lower value on monetary returns than poorer, lower status parents". Osterbeek and van Ophem (2000) find support for this; the consumption motive for the educational choice seems to be more important the higher the social background the individual has, and the better

\footnotetext{
${ }^{13}$ Acemoglu (1995) mentions as an example the fall and rise of the merchant's status in the Mediterranean area: "The arrival of Islam in the Mediterranean in the eight century stopped commerce through this sea to a large extent. This lead to the disappearance of merchants. In the twelfth century, the Christian counterattack against Islam started and Europeans took once again control of the Mediterranean. This gradually led to the renewed trade and to the activity organized around towns and merchants."
} 
skilled he is. They also find that children of highly educated fathers or fathers with higher level occupations have lower discount rates than children of lower educated fathers or fathers with lower level occupations. This means that a child from a poorer family seems to attach lower weight to future earnings than children in richer families do.

As individuals' preferences might change over time, so might their discount rates. Most individuals acquire higher education when they are young. One could claim that young people in general have short time horizons and high discount rates when making their choices. Thus they put more weight on the present consumption value of education than on the future income possibilities when making their educational choice. Later in life they might regret this and have a lower willingness to pay for the consumption value of education (measured in forgone labor income). This type of time inconsistency and hyperbolic discounting is discussed by Ainslie and Haslam (1992). This problem is avoided in the following empirical analysis by applying the individuals' ex-ante preferences in the estimation of the price of the consumption value of education and assuming a constant discount rate.

Social returns to education. The altered preference structures during the educational process have positive effects on the welfare in the society if they induce the individual to take better care of his health and to become a better citizen. Lochner and Moretti (2001) find that education has a causal negative effect on incarceration, Lleras-Muney (2002) finds that education has a causal negative effect on mortality, while Milligan et al. (2003) find that schooling improves civic participation in political processes. Also, higher education has a positive effect on economic growth through technological innovation from increased knowledge spill-overs (Lucas, 1988, and Romer, 1990). These are all reasons why many countries subsidize higher education substantially.

\subsection{Uncertainty.}

As the individual makes his educational choice based on his expectations of the returns to the investment, both pecuniary and non-pecuniary, there is considerable uncertainty present. It might very well be that he has incomplete information of the content and thus also the consumption value of the education, or that his preferences 
change during the education process, as discussed above. Also, since there is a substantial lag from when the investment decision is made to when the pecuniary return is generated, he needs to make this investment decision based on his expectations of future wages, job openings, taxes etc. Due to poor information, business cycles, politics, and his future health these expectations are uncertain and very much based on the present situation in the society at the time when he makes his educational choice. When making his educational choice, the individual has a full range of types to choose from, but after the completion of the education he has limited options of which careers to pursue, and this represents a potential lock-in effect.

\section{A method for measuring the consumption value of higher education.}

I apply the compensating differentials framework to measure the consumption value of teacher's college. The model is described below, along with the data and the approach to correct for the innate abilities of the individuals. The results are presented and discussed in the last part of this section.

\subsection{Compensating differentials.}

Rosen (1986) states that the theory of compensating differentials "refers to observed wage differences required to equalize the total pecuniary and non-pecuniary advantages or disadvantages among work activities and among workers themselves". A modified version of Rosen's model will in the following be applied to measure one particular individual's valuation of the consumption value of type- $A$ education when type- $B$ education is used as benchmark.

The individual maximizes his utility $U$, which depends positively on both ordinary consumption $C$ and the consumption value $e_{i}$ of education $E_{i}$ :

$$
U=u\left(C, e_{i}\right), \quad i=A, B .
$$

$e_{i}$ is an index of the consumption value of type- $i$ education; the higher the consumption value, the higher the value of $e_{i}$. The consumption value index is individual specific, such that when one individual has higher consumption value of type-A education, another individual may have higher consumption value of type-B education. 
Assume that all income is consumed, and that the individual only lives for one period. He acquires education in the beginning of the period and works and consumes in the end of the period. His consumption level thus equals his wage income, $C=w_{i}$, where the net of taxes wage level depends on the type of education chosen. The individual's utility function can be written as

$$
U=u\left(w_{i}, e_{i}\right), \quad i=A, B
$$

Both variables are continuous, and fringe benefits are not considered. There are no non-wage types of monetary income in the model. This is a one-period model, but $w_{i}$ and $e_{i}$ can be viewed as the present values of lifetime income and consumption value that the individual experiences by choosing type- $i$ education. At the beginning of the period the individual makes his educational choice, and he may choose between the two educational types $A$ and $B$, which differ in both consumption value and wage return. For this particular individual, type-A education has the higher consumption value:

$$
e_{A}>e_{B}
$$

For a given wage return, $\bar{w}$, to both kinds of education, the individual always prefers type-A education, since it holds the higher consumption value to him:

$$
u\left(\bar{w}, e_{A}\right)>u\left(\bar{w}, e_{B}\right) .
$$

The decision is more complicated if the wage return differs between the two types of education. Then the combination of individual preferences, wage return, and consumption value of the educational type determines which is preferred. Let $w_{B}^{*}$ be the wage return to type-B education that the individual requires in order to be indifferent between the two educational types when type-A education has the wage return $w_{A}$ :

$$
u\left(w_{A}, e_{A}\right)=u\left(w_{B}^{*}, e_{B}\right) .
$$

Since type-B education is never preferred to type-A education if they have the same wage return, it follows that

$$
w_{B}^{*}>w_{A}
$$

Now define the difference

$$
D=w_{B}^{*}-w_{A}
$$

as the individual compensating differential for type-A education compared with typeB education. The individual compensating differential $D$ is the additional wage 
return to type-B education necessary to make the individual indifferent between the two educational types at their given consumption values. Thus $D$ is the wage return that the individual is willing to forgo in order to enjoy the consumption value $e_{A}$. This willingness to pay for the consumption value of type-A is individual specific. For now we only consider one individual, but when we expand the model to consider a group of individuals, $D$ will vary among the individuals choosing type-A education.

Let $W$ be the market compensating wage differential, defined as the difference in the market wage returns to type-B and type-A education.:

$$
W=w_{B}-w_{A}
$$

The market offers the individual the additional wage return $W$ if he chooses type$\mathrm{B}$ education and forgoes the consumption value he could have enjoyed by choosing type-A education. If the individual compensating wage differential is the same as the market compensating wage differential, $D=W$, then the individual is indifferent between the two types of education. If $D<W$, the market offers a greater wage compensation for choosing type-B education than is required by the individual. He chooses type-B education and thus increases his consumption level by more than what is required to compensate for the utility loss by not enjoying the consumption value of type-A education. On the other hand, if $D>W$, the individual chooses typeA education, since the wage premium by choosing type-B education is less than what is required to compensate for the utility loss he experiences by not choosing type- $\mathrm{A}$ education.

Now consider figure 1, where an example of one particular preference structure is displayed. Type-A education offers the reward structure $\left(e_{A}, w_{A}\right)$, point $a$, and type$\mathrm{B}$ education offers the reward structure $\left(e_{B}, w_{B}\right)$, point $b$. The individual requires the wage $w_{B}^{*}$ in order to be indifferent between the two kinds of education, and here $w_{B}^{*}>w_{B}$. The individual compensating wage differential, $D$, is given by the vertical distance between points $c$ and $a$, while the market compensating wage differential, $W$, is given by the vertical distance between the points $b$ and $a$. Thus, at this given preference structure and wage structure the individual is undercompensated by the wage return to type-B education for forgoing the consumption value of type- $\mathrm{A}$ education, $D>W$, and the individual chooses type-A education.

The market compensating wage differential, $W$, is the market price of the consumption value of type-A education, and it is available to all individuals. Still, 
Figure 1: Individual and market wage differentials and the choice of educational type.

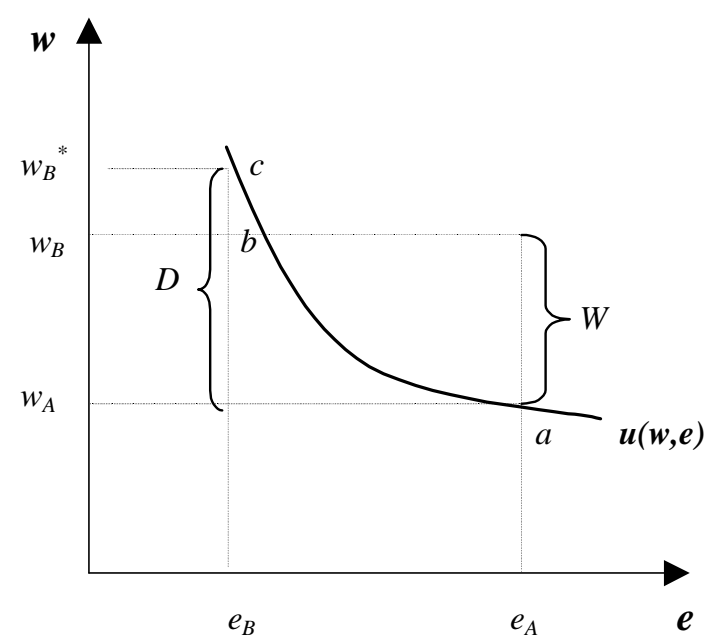

individuals differ in their preferences, and so does the individual compensating wage differential, $D$. As an example, let the educational preferences of all individuals be distributed over the individual taste variable $D$ as illustrated in figure 2. Assume that they all have the same level of innate abilities. The average value of the individual compensating wage differential is represented by $E(D)$. As already discussed, the individual's preferences might change due to external influences. This would shift the distribution of preferences and also the average value of the individual compensating wage differential. The market offers the compensation $W$ to the individuals who forgo the consumption value of type-A education and instead choose type-B education. In this specific case $W<E(D)$, and the majority of the individuals choose type-A education, since the forgone labour income by doing so is less than the price they are willing to pay for the consumption value of type-A education, $D$. As $W$ increases, some individuals are no longer willing to forgo that high a wage return in order to enjoy type-A education, and more individuals choose type-B education. The individuals who choose type-B education have the lowest preferences for the consumption value of type-A education. Since individuals differ in taste, their reservation wage return, $D$, also differs. This ensures the existence of economic rent in the labour market. Most individuals who choose type-B education receive an economic rent of the size $W-D$. The marginal individuals earn no economic rent, while most individuals who choose type-A education also receive an economic rent, since their 
Figure 2: Distribution of individual compensating wage differentials and the choice of educational type.

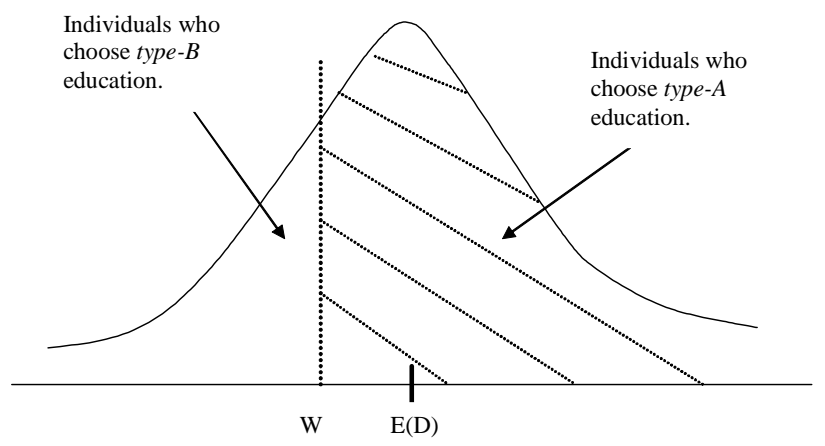

willingness to pay for the consumption value of type-A education is higher than the actual price demanded by the market in the form of the market compensating wage differential. The conclusion from this is that the market compensating wage differential $W$ serves as a lower bound on the willingness to pay for the consumption value of type-A education among the individuals choosing it.

Income taxes. In the above model, the market compensating wage differential $W$ is defined in the absence of taxes. Intuitively, one would expect income taxes, $T$, to reduce the net market compensating wage differential, $W_{n}$, available to the individual:

$$
W_{n}=W-T
$$

The consumption value of education is a tax free return to human capital investments. Progressive income taxes reduce the wage return to type-B education relatively more than the wage return to type-A education, and this could reduce the net market compensating wage differential. See Alstadsæter (2003) for a discussion of how the tax system might induce the individuals to choose more of the educational type with the higher consumption value.

But the above discussion implicitly assumes that the gross wage differential is unaffected by taxes, which is usually not the case. As Persson and Sandmo (2002) show in a special case, increased progressivity in the tax schedule might actually lead to higher after tax wage inequality. To say anything about the effects of different 
tax schedules on the net of taxes wage differentials requires a thorough discussion on the wage determination mechanisms, but this goes beyond the scope of the paper.

Selection problem. The market compensating wage differential might be measured by comparing two types of education with different consumption values. If all individuals had the same level of innate abilities, the difference in the wage return to the two educational types would be the individual's average minimum willingness to pay for the consumption value of the more beneficial educational type. But different individuals have different innate abilities, experiences, and personalities. The wage return to the educational type is now partly endogenous, depending on innate individual ability. The individuals also have different views on which educational type has the higher consumption value.

The selection problem can be accounted for by finding two individuals with the same level of innate ability, but who have different preferences and make different educational and career choices. One possible approach to this is the growing identical-twin study literature (see Ashenfelter and Rouse, 1998). This strand of literature utilizes surveys on identical twins, who are assumed to have the same level of innate abilities. The wage return to one additional year of education is estimated by using the earnings of the other twin as a benchmark for the given ability level. But this method is controversial. Bound and Solon (1999) state that "even monozygonic twins are a little different, and their (often small) differences in abilities and temper may contribute to their (often small) differences in schooling."

This paper proposes an alternative approach. The identification strategy is to compare individuals with approximately the same grade level at high school graduation, but who choose different types of higher education. Grades are here used as an instrument for ability. The individuals who attended teacher's college (typeA education) during the 1960's could have attended business school (type-B) and experienced a much higher wage return but chose the higher consumption value of teacher's college. Thus wage return to business school is the benchmark for their potential future wage return ${ }^{14}$. The educational choice here also implicitly means

\footnotetext{
${ }^{14}$ This does not mean that business school has a low or negative consumption value for the individuals actually choosing to attend business school. It might very well be that these individuals' preferences are such that they have a high consumption value from attending business school. Here we look at the issue from the point of view of the individuals who actually chose teachers'
} 
a choice of sector, since most teachers work in the public sector and a majority of business school graduates work in the private sector.

\subsection{The consumption value of teacher's college.}

Teaching used to be considered a noble profession, and as late as in the 1960's many considered teaching a calling ${ }^{15}$, and admission requirements were strict. It is remarkable that teaching was such a popular profession, seeing that teachers had modest salaries compared with many other jobs available to skilled individuals ${ }^{16}$. One reason for this is that the gender wage discrimination was small among teachers, and that it was a profession easier for women to combine with raising children. Women go in and out of the labor force more frequently than men and, in addition, few women attended business school in the 1960's. Thus only males are considered here.

The remaining explanation for the high popularity of teacher's college is the high consumption value of this educational type. Teacher's college covers a broad range of different subjects, where the students themselves choose which to specialize in, according to their interests. Also, this field of study is considered to be less demanding and time consuming than many others, leaving more time for leisure and extra curricular activities during the education ${ }^{17}$. After completed education, teacher's college graduates can expect to have more leisure, since teachers have longer holidays. Teachers can get jobs all over the country, and are not bound to live in the larger cities, as are many other of the highly educated individuals, and this might play an important role for individuals planning to live in particular areas. The individuals choosing teacher's college have such a high consumption value of

college, even though they could have attended business school and increased their lifetime income substantially (as is shown later in this paper). These individuals most certainly expected a positive consumption value of education that was at least as large as the difference in the expected wage returns to the two kinds of education.

${ }^{15}$ The author's own observations by reading arhived letters to the admission board.

${ }^{16}$ See Aarrestad (1969).

${ }^{17}$ This is here defined as a part of the consumptiton value, since the individual enjoys having a more relaxed life and being able to pursue his other interests. But it might as well be defined as a part of the investment costs, since it means that the teacher's college student needs to invest less effort to graduate than his business school counterpart. 
this education that they willingly give up the future wage return they could have achieved by choosing another type of education.

Business school is another field of study ${ }^{18}$ that requires a high grade level from high school in order to be admitted. During the 1960's the admission requirements were just as strict for both these fields of study ${ }^{19}$, but the wage return to business school was superior to that to teacher's college, as pointed out by Aarrestad (1969, 1972). Even though the teacher's college graduates could have attended business school and had a higher wage return, they still chose to attend teacher's college. Hence they were willing to forgo future wages in order to enjoy the consumption value of teacher's college. Of course, they could have chosen other fields of study as well, but business school is chosen as a benchmark because it has the same admission requirements.

We now apply the model developed in the previous section to calculate $W$, the lower limit of the teacher's college graduates willingness to pay for the consumption value of teacher's college in the 1960's. A unique Norwegian panel data set provides very complex information on all these individuals. Unfortunately, there is no information on actual working experience for the individuals in question, and thus the potential experience approach of Mincer is applied. Define potential experience, $X_{p}$, for each year as the age of the individual minus the age at school enrollment minus the duration of the education minus a year for mandatory military service. Both the expected price of the consumption value of teacher's college at the time of the educational choice and the actual price these individuals finally paid are calculated.

\subsection{Measuring the ex-ante price of the consumption value of teacher's college.}

The 1970 household census holds information on among other things educational type, gross earnings, and age for all Norwegian adults. Utilizing this information, the earnings by experience profiles for individuals with teacher's college and business school are estimated. These cross-section wage profiles are interpreted as the teacher's college and business school attendants' expected future earnings profiles

\footnotetext{
${ }^{18}$ Business school was attended directly after high school and had a duration of three years during the 1960's. It was expanded to a four year duration in 1975.

${ }^{19}$ See the appendix for more details.
} 
Figure 3: 1970 gross wage profiles for males with teacher's college and business school, by years of potential experience.

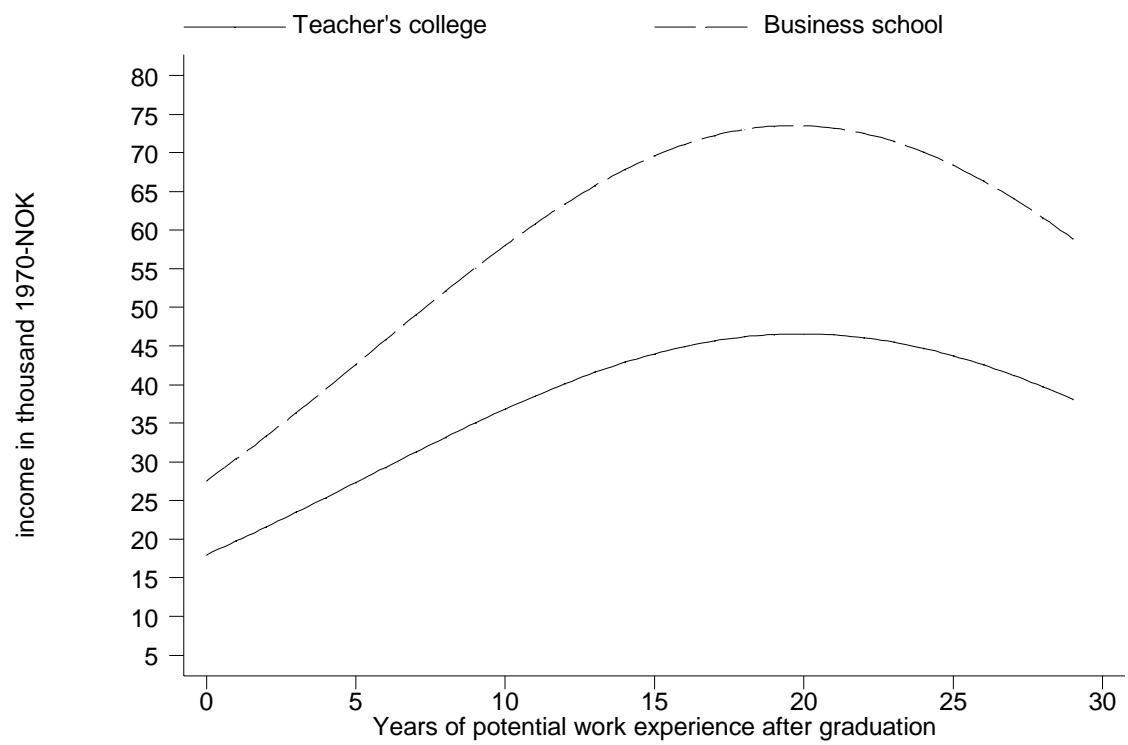

in the late 1960's.

The estimation approach differs from that of Mincer, since the duration of the education is fixed. The specification below is estimated separately for each group using ordinary least squares:

$$
\ln W=\alpha_{1}+\alpha_{2} X_{p}+\alpha_{3} X_{p}^{2}+\epsilon
$$

From the estimation results (reported in figures 7 and 8 in the appendix) we conclude that even though there are some differences in the return to experience in favor of business school graduates, the major difference is between the constant $\alpha_{1}$ in the two groups. Teacher's college graduates actually start their career with gross earnings $34.7 \%$ below that of business school graduates ${ }^{20}$.

Smoothed versions of the wage profiles for 29 years of work experience from the 1970 census are shown in figure 3. The teacher's college graduates pay a substantial wage premium in order to enjoy the consumption value of their educational type, and this wage premium increases over their career. The earnings vary more among business school graduates than among teacher's college graduates. This may

\footnotetext{
${ }^{20}$ The estimation results are here transformed to NOK before finding the wage gap between the two groups.
} 
Figure 4: Present values of 29 years worth of labor experience in thousand 1970NOK, calculated from the average earnings of males at different levels of working experience in the 1970-cencus. These are the gross expected average lifetime earnings of individuals choosing teacher's college and business school in the 1960's.

\begin{tabular}{|lccccccc|}
\hline Discount rate: & $\underline{\mathbf{2} \%}$ & $\underline{\mathbf{3} \%}$ & $\underline{4 \%}$ & $\underline{\mathbf{5 \%}}$ & $\underline{6 \%}$ & $\underline{\mathbf{7 \%}}$ & $\underline{\mathbf{8 \%}}$ \\
Business school: & 1345 & 1164 & 1015 & 892 & 789 & 702 & 629 \\
$\begin{array}{l}\text { Teacher's college: } \\
\begin{array}{l}\text { Expected price on teacher's } \\
\text { college as a consumption } \\
\text { good: }\end{array}\end{array}$ & $\mathbf{8 3 1}$ & 719 & 627 & 550 & 487 & 433 & 388 \\
$\begin{array}{l}\text { Expected price as percentage } \\
\text { of potential income: }\end{array}$ & $\mathbf{3 8 . 2}$ & $\mathbf{3 8 . 2}$ & $\mathbf{3 8 . 2}$ & $\mathbf{3 8 . 3}$ & $\mathbf{3 8 . 3}$ & $\mathbf{3 8 . 3}$ & $\mathbf{3 8 . 3}$ \\
\hline
\end{tabular}

to some extent be due to the fact that most teachers work in the public sector where the wage level is set by centralized negotiations. The government is the employer and exercises monopsony power, since the private labor market for teachers is very limited. Business school graduates, on the other hand, mostly work in the private sector, where wage negotiations are local and the wage structure is more flexible.

The earnings of the business school graduates constitute the potential total income for the teacher's college graduates. Hence their minimum willingness to pay for the consumption value of teacher's college is the market compensating wage differential. The start up wage differential is $34.7 \%^{21}$ of the teacher's college graduates' potential lifetime income. But as the wage differential increases over the career, one would expect the present value of the life time wage differential to be higher. The exact size of this wage premium is not available directly from this estimation.

By applying the average wage at all levels of experience, the present value of the lifetime income ${ }^{22}$ can be calculated for both business school graduates and teacher's college graduates. The results are shown in the table in figure 4, calculated at differ-

\footnotetext{
${ }^{21}$ This is in line with Aarrestad's (1969) results from his small sample survey in 1967.

${ }^{22}$ Assume here that the duration of the working period of the individual is 29 years. The reason why this exact period is chosen, is that there are few observations in the sample with longer potential working experience. This is to a great extent due to the early classes of business school being small.
} 
ent discount rates. Independent of the discount rate, the wage gap between the two groups is substantial. Teacher's college graduates pay a price for the consumption value of their education in the size of $38 \%$ of the present value of their potential gross lifetime income.

These are gross wages and, as previously discussed, the presence of a progressive income would tax most likely reduce the wage gap and thus the price on teacher's college as a consumption good. The existence of a substantial willingness to pay for the consumption value of teacher's college is still nondismissable.

Some objections. Only annual earnings are available in the data. Hence part of the wage gap might be due to differences in hours worked instead of wage differences.

There are no tuition fees at Norwegian universities, but the students still have to finance their living expenses. The existence of publicly provided and subsidized student loans eliminates, or at least reduces, the liquidity constraints that might otherwise be present. For most of the 1960's teacher's college had a two-year duration, while business school had a three-year duration. Thus, the major cost of acquiring higher education, namely forgone labor income, is higher for business school graduates. Therefore part of the wage gap between the two educational types is compensation for the higher investment costs of business school.

The different duration of the two educational types also matters if the individual has a high discount rate. He then wants to start earning money as soon as possible, which might induce him to choose teacher's college rather than business school.

Geographical differences might matter. During the 1960's there were teacher's colleges all over the country, and the individual who disliked moving had a good chance of finding a teacher's college close to home. Business school, on the other hand, for a long time only existed in Bergen (The Norwegian School of Economics and Business Administration), but later another school was founded in Oslo (The Norwegian School of Management). This could also induce the individual to choose teacher's college over business school. 


\subsection{Measuring the ex-post price of the consumption value of teacher's college.}

The previous section estimated the ex-ante willingness to pay for the consumption value of teacher's college among the individuals acquiring their education in the 1960's. Did these individuals end up paying a higher or lower price than expected for this consumption value?

We now estimate the actual wage profiles of all individuals attending and graduating from business school and teacher's college during the 1960's. By combining the earnings register and the core administrative register we have information on each individual's income from 1967 to 2000, along with rich information including factors such as educational type, graduation date, and birth date. Each individual now has several entries in the created cross section set of annual earnings per year of potential experience. Apply the same empirical specification as in equation (7), but following Klette and Møen (2002), this time use a random effect regression to estimate the return to potential experience separately for the two educational groups. The estimation results are reported in figures 9 and 10 in the appendix, and smoothed wage profiles for the two groups are drawn in figure 5.

It is clear that the ex-post wage profiles differ quite a lot from the ex-ante wage profiles. It is rather surprising, though, that the wage gap at the beginning of the career is smaller than predicted. The teacher's college graduates started their careers with annual gross earnings $20.6 \%$ below that of the business school graduates, where the corresponding ex-ante wage gap was $34.7 \%$. But business school graduates experience rapid wage increases over their careers, relative to the teacher's college graduates, as is clearly seen in figure 5 . This would have a large impact on the present value of the two groups' lifetime income.

Since the wage differential increases heavily over the years, the present values of the two groups' actual lifetime income depends on which discount rate is chosen, as shown in the table in figure 6 . The more weight the individual puts on future earnings, the lower his discount rate, and the higher the price of the consumption value of teacher's college measured in forgone potential income. The ex-post price on the consumption value of teacher's college is between $45 \%$ and $48 \%$ of the individuals' potential lifetime income, depending on the discount rate. This is substantially higher than the ex-ante price of $38 \%$ of their potential lifetime income. Some of the 
Figure 5: The actual deflated gross wage profiles of individuals attending teacher's college and business school in the 1960's, by years of potential experience after graduation.

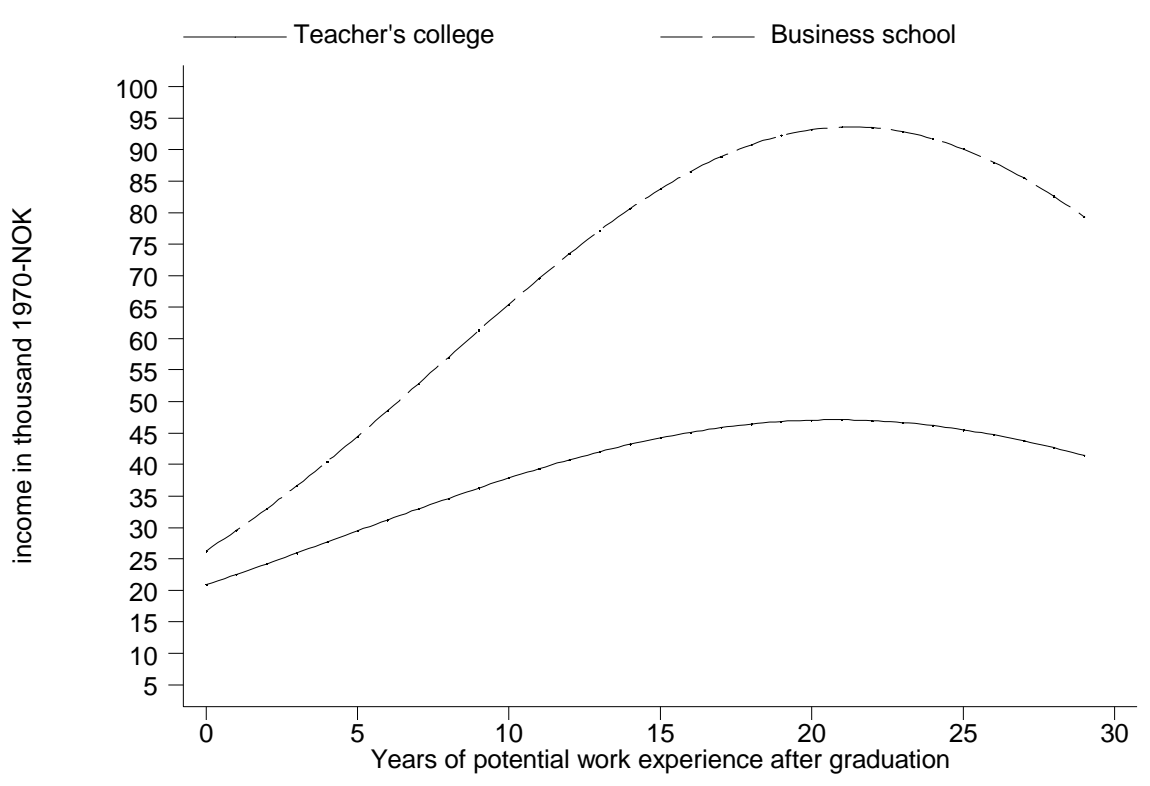

reason for these high wage differentials might be that observations from the 1980's are included in the sample, a period where the private sector enjoyed a high wage increases relative to the public sector.

The ex-ante wage profiles were estimated on cross-section data from 1970, while the ex-post wage profiles were estimated as cross-section variation between individuals observed over 29 years. During this time period, the tax system changed several times, both changing the tax base as well as the marginal tax rates. The higher the marginal tax rates in the higher income brackets, the more one would expect the net of taxes wage gap between the two groups to be reduced. Still, even though the marginal tax rates have been reduced over the years, the tax base has been broadened, such that it is not possible to say whether these reduced marginal tax rates increased the net of tax wage differentials or not. A thorough analysis is required to answer this, and that is left for future research. The main objective of this paper is to establish as a fact that individuals have high willingness to pay for the consumption value of education, rather than to find the exact size of this net of taxes willingness to pay. 
Figure 6: Present values of 29 years worth of labor experience in thousand 1970NOK, calculated at different discount rates. These are the actual average gross lifetime earnings of individuals choosing teacher's college and business school in the 1960's. Data from the earnings and pension registers, only males.

\begin{tabular}{|c|c|c|c|c|c|c|c|}
\hline Discount rate: & $\underline{2} \%$ & $3 \%$ & $\underline{4 \%}$ & $\underline{5 \%}$ & $\underline{6 \%}$ & $\underline{7 \%}$ & $\underline{8 \%}$ \\
\hline Business school: & 1734 & 1486 & 1283 & 1116 & 978 & 863 & 767 \\
\hline Teacher's college: & 896 & 777 & 679 & 597 & 529 & 472 & 423 \\
\hline $\begin{array}{l}\text { Actual price on teacher's college } \\
\text { as a consumption good: }\end{array}$ & 837 & 709 & 604 & 519 & 449 & 391 & 343 \\
\hline $\begin{array}{l}\text { Actual price as percentage of } \\
\text { potential income: }\end{array}$ & 48.3 & 47.7 & 47.1 & 46.5 & 45.9 & 45.3 & 44.8 \\
\hline
\end{tabular}

Further objections. The estimated wage gaps do not account for the fact that teachers are provided with a public sector retirement insurance, while these retirement insurances vary in both extent and quality in the private sector. If pension benefits had been included in the earnings profiles, it might be that the wage gap between the two groups had been smaller.

We have to some extent controlled for heterogeneity in ability among individuals by comparing two types of educations with the same cut-off grade level requirements from high school. But it is not certain that the upward ability distribution is the same in the two groups, such that some heterogeneity might still exist. Teachers mostly get the same wage independent of performance, while wages are more individual specific in the private sector. Hence the wage incentives to choose business school are higher the more skilled the individual.

Also, the approach in this paper corrects for the level of the innate abilities, but not the difference in types of ability. Willis and Rosen (1979) found that a person chooses the kind and length of education that maximize his income. They only consider monetary income, but the results may also be interpreted to include non-monetary income. This means that a good lawyer would not necessarily have made a good plumber, and that the individuals maximize their income and utility according to their abilities and preferences ${ }^{23}$ Both teacher's college and business

\footnotetext{
${ }^{23}$ This is in contrast to the one-factor-ability-as-IQ literature that says that the best lawyers would also have made the best plumbers.
} 
school are still pretty much all-round types of educations, with a broad range of different subjects. Also, admissions are made based on the average grade level from high school, meaning that the students need good all-round skills.

\section{Conclusion.}

This paper argues for the existence of an individual specific consumption value of education, both during the education and after its completion, and for which the individual is willing to pay. A method for measuring the willingness to pay for the consumption value of education where the innate ability bias is corrected for is suggested in a compensating differentials framework.

On rich Norwegian cross section data it is estimated that the individuals who attended teacher's college in Norway during the 1960's expected to start their first job with annual earnings $34.7 \%$ below their potential earnings. The full ex-ante price for the consumption value of teacher's college is estimated to be $38 \%$ of the present value of the individual's potential lifetime income.

Utilizing a full coverage panel data set on the Norwegian population it is estimated that the teacher's college graduates in fact started up their first job earning "only" $20.6 \%$ less than the business school graduates. However these wage differentials increased over time. The ex-post price on the consumption value to teacher's college during the 1960's turned out to be about $46 \%$ of the present value of the individuals' potential lifetime income.

The goal of the paper has not been to find an exact value of the willingness to pay for the consumption value of education, but rather to establish as a fact that the consumption value of education does exist and that it is an important factor behind the individual's educational choice. As the example shows, many individuals are willing to give up substantial future wage returns in order to acquire the education of their choice. Therefore, the consumption value of education should not be ignored when modeling the individual's educational choice and estimating the return to education. 


\section{References.}

Aakvik, A., K.G. Salvanes and K. Vaage (2003): Measuring heterogeneity in the returns to education in Norway using educational reforms. CEPR Working Paper No. 4088.

Aarrestad, J. (1969): Om utbyttet av å investere i utdanning i Norge. Skrifter, Serie A, Nr.1, Norwegian School of Economics and Business Administration.

Aarrestad, J. (1972): Returns to higher education in Norway. Swedish Journal of Economics 2, 263-280.

Acemoglu, D. (1995): Reward structures and the allocation of talent. European Economic Review 39, 17-33.

Ainslie, G. and N. Haslam (1992): Hyperbolic discounting. In G. Loewenstein and J. Elster (eds.): Choice over time. Russel Sage, New York, 57-92.

Alstadsæter, A. (2003): Income tax, consumption value of education, and the choice of educational type. CESifo Working Paper No. 1055.

Antos, J.R, and S. Rosen (1975): Discrimination in the market for public school teachers. Journal of Econometrics 3, 123-150.

Arcidiacono, P. (2002): Ability sorting and the returns to college major. Duke Economics Working Paper No. 02-26.

Ashenfelter, O. and C.E. Rouse (1998): Income, schooling and ability: evidence from a new sample of identical twins. Quarterly Journal of Economics 113, 253-284.

Becker, G.S. (1996): Accounting for tastes. Harvard University Press, Cambridge, Massachusetts.

Becker, G.S. (1964): Human capital. A theoretical and empirical analysis with special reference to education. University of Chicago Press, 3rd edition 1993.

Becker, G.S. and K.M. Murphy (1988): A theory of rational addiction. Journal of Political Economy 96(4), 675-700. 
Bishop, J. (1994): Schooling, learning and worker productivity. In Rita Asplund (ed.): Human Capital Creation in an Economic Perspective. Physica-Verlag.

Bound, J. and G. Solon (1999): Double trouble: on the value of twins-based estimation of the return to schooling. Economics of Education Review 18(2), $169-82$.

Bowles, S. (1972): Schooling and inequality from generation to generation. Journal of Political Economy 80, 219-251.

Card, D. (1999): The causal effect of education on earnings. Handbook of Labor Economics, volume 3, 1801-1863.

Chiswick, B.R. (2003): Jacob Mincer, experience and the distribution of earnings. IZA Discussion Paper No. $84 \%$.

Croix, D. de la (2001): Growth dynamics and educational spending: The role of inherited tastes and abilities. European Economic Review 45, 1415-38.

Dolton, P.J., G.H. Makepeace, and W. van der Klaauw (1989): Occupational choice and earnings determination: The role of sample selection and non-pecuniary factors. Oxford Economic Papers 41, 573-594.

Duncan, G.J. (1976): Earnings functions and nonpecuniary benefits. Journal of Human Resources 11(4), 462-483.

Gullason, E.T. (1989): The consumption value of schooling. An empirical estimate of one aspect. Journal of Human Resources 24(2), 287-98.

Hægeland, T., T.J. Klette, and K.G. Salvanes (1999): Declining returns to education in Norway? Comparing estimates across cohorts, sectors and over time. Scandinavian Journal of Economics 101, 555-576.

Judd, K. (2001): The impact of tax reform in modern dynamic economies. In K.A. Hasset and R.G. Hubbard: Transition costs of fundamental tax reform. The AEI Press, Washington D.C.

Keane, M.P. and K.I. Wolpin (1997): The career decision of young men. Journal of Political Economy 105(3), 473-522. 
Klette, T.J. and J. Møen (2002): Vitenskapelig forskning og næringsutvikling. In E. Hope (ed.): Ncringspolitikk for en ny økonomi. Fagbokforlaget.

Kodde, D.A. and J.M.M. Ritzen (1984): Integrating consumption and investment motives in a neoclassical model of demand for education. Kyklos 37(4), 598605.

Lazear, E. (1977): Education, consumption or production? Journal of Political Economy 85(3), 569-597.

Lleras-Muney, A. (2002): The relationship between education and adult mortality in the United States. NBER Working Paper No. 8986.

Lochner, L. and E. Moretti (2001): The effects of education on crime: Evidence from prison inmates, arrests, and self-reports. NBER Working Paper No. 8605.

Lucas, R.E. (1988): On the mechanics of economic development. Journal of Monetary Economics 22, 3-42.

Marshall, A. (1920): Principles of economics, 8th ed. Macmillian, London.

Mincer, J. (1974): Schooling, experience and earnings. Columbia University Press, New York.

Milligan, K., E. Moretti and P. Oreopoulos (2003): Does education improve citizenship? Evidence from the U.S. and U.K. NBER Working Paper No. 9584.

Nerdrum, L. (1999): The economics of human capital. A theoretical analysis illustrated empirically by Norwegian data. Scandinavian University Press.

Oosterbeek, H. and H.V. Ophem (2000): Schooling choices: Preferences, discount rates, and rates of return. Empirical Economics 25, 15-34.

Oosterbeek, H. and D. Webbink (1995): Enrolment in higher education in the Netherlands. De Economist 143, 367-380.

Oreopoulos, P. (2003): Do dropouts drop out too soon? International evidence from changes in shool-leaving laws. INBER Working Paper No. 10155.

Persson, M. and A. Sandmo (2002): Taxation and tournaments. NHH Discussion Paper No. 10. 
Romer, P.M. (1990): Endogenous technological change. Journal of Political Economy 98, 71-102.

Rosen, S. (1986): The theory of equalizing differences. In O. Ashenfelter and R. Layard (eds.): Handbook of Labour Economics, Vol. 1, 641-692.

Sandmo, A. (1983): Ex post welfare economics and the theory of merit goods. Economica 50, 19-33.

Schaafsma, J. (1976): The consumption and investment aspects of the demand for education. Journal of Human Resources 11(2), 233-42.

Schultz, T.W. (1960): Capital formation by education. Journal of Political Economy $68,571-582$.

Scitovsky, T. (1976): The joyless economy. Oxford University Press.

Scott, A. (2001): Eliciting GP's preferences for pecuniary and non-pecuniary job characteristics. Journal of Health Economics 20, 329-347.

Smith, A. (1776): The Wealth of Nations. Reprint 1999, Penguin Classics, London.

Stern, S. (1999): Do scientists pay to be scientists?, NBER Working Paper No. 7410.

Wangen, K.R. (2003): En konsuments kvaler ved vanedannelse og nåtidsskjevhet. Økonomisk Forum 57(4).

Ward, M.E. and P.J. Sloane (2000): Non-pecuniary advantages versus pecuniary disadvantages; job satisfaction among male and female academics in Scottish universities. Scottish Journal of Political Economy 47(3), 273-303.

Weisbrod, B.A. (1962): Education and investment in human capital. Journal of Political Economy 70(5), Supplement, October, Part II, Investment in Human Beings, 106-123.

Willis, R.J. and S. Rosen (1979): Education and self-selection, Journal of Political Economy 87(5), 7-36. 


\section{Appendix}

\subsection{Documentation of admission requirements.}

It is a general perception that during the 1960's it was just as difficult to be admitted to teacher's college as to business school in Norway. Aarrestad (1969) stated ${ }^{24}$ on page 69: "The demand for teacher's college education far exceeds the supply. The minimum requirement for admission has the last years been above 60 grade points (from high school)." Also, on page 75 he states: "The admission requirements for the Norwegian School of Economics and Business Administration are not quite clear. With maximum awarded additional points, it is today possible to be admitted with about 60 grade points from high school."

It proved difficult to find formal evidence for these admittance requirements. In the archives of the Norwegian School of Economics and Business Administration ${ }^{25}$ and of the Teacher's Council ${ }^{26}$ I found indications that the last student admitted to teacher's college and to business school had about the same grade levels, but no official statistics are available on this issue. Another problem with comparing the two is that the different institutions had different regulations for giving so-called additional points to the applicants, such that their total competitive grade score varied from their high school graduation grade score. Additional points were awarded for previous education and work experience, and for extracurricular activities, but the praxis varied among the institutions.

\section{$7.2 \quad$ Data}

The 1970 Household Census covers all Norwegian households and individuals (identified by their personal identification number). The census contains information on among other things on gross income, sex, age, marital status, type and level of education, and personal income.

\footnotetext{
${ }^{24}$ The following quotations are translated from Norwegian.

${ }^{25}$ For a long time this was the only business school in Norway, but at the and of the 1960's another one was founded as well.

${ }^{26}$ From about 1967 admission to all teacher's colleges in Norway was organized centrally by the Teacher's Council (Lærerutdanningsrådet). Before that time the admission was organized by each school, and the requirements varied from school to school.
} 
The Earnings Register covers all Norwegian adults and contains gross individual earnings based on pension rights earned over the period 1967-2000.

The Core Administrative Register contains information on all Norwegians in the years 1986-2000. It has among many other variables age, sex, marital status, type and length of highest completed education, graduation date. The income history of the individuals can be extended by including the earnings history of the individuals from the earnings register.

The cleaned sample for calculation of the ex-ante wage profiles. Individuals with missing observations on either educational type or income are removed from the sample. Beyond that all individuals who graduated from teacher's college or business school in the period 1941-1970 are included in the sample, in order to estimate the full income profile for 0-29 years of working experience in 1970 for the two groups. Even individuals who for some reason were not active in the labor force are included. When a young person makes his educational choice, the future wage return is uncertain for many reasons, and one of them is that he might become ill and be unable to work. If one type of education leads to more stressful jobs than the other, more individuals will become ill, and the wage level while still at work needs to be higher in order to compensate for this. Hence the income of those not currently in the labor force in 1970, but with potential labor experience between 0 and 29 years, needs to be included to get the full picture.

The full sample of males in the 1970 census counts 2269 business school graduates and 7089 teacher's college graduates.

The cleaned sample for calculation of the ex-post wage profiles. The first challenge was to identify who acquired the two educational types during the 1960's, as well as to find their potential working experience. In principle, I could use the graduation date in the core administrative register to establish when the individual most likely started working, and thus find the potential working experience in years. Unfortunately, all who completed their education prior to November 1970 are listed with this as their graduation date. Therefore I use their date of birth, add 19 years (to complete high-school) to find the time when they most likely started their higher education, and add another 2 or 3 years to find graduation date. Finally I added another year for the mandatory military service (some did this before and others 
after their education, but most did it before they started working) to find when they most likely started their professional careers.

This procedure identified the individuals acquiring their education during the 1960 's, as well as their entry into the labor force. By merging the core administrative data with the earnings register, I got the gross income series for these individuals from 1967 to 2000. From this the earnings history of the individuals from 0 to 29 years of potential experience was extracted.

When the panel was cleaned for entries missing information on annual earnings, the final sample consisted of 465 business school graduates with a total of 13110 observation entries, and 1805 teacher's college graduates with a total of 50153 observation entries. 
Figure 7: Results, ordinary least squares regression, teachers, 1970-census.

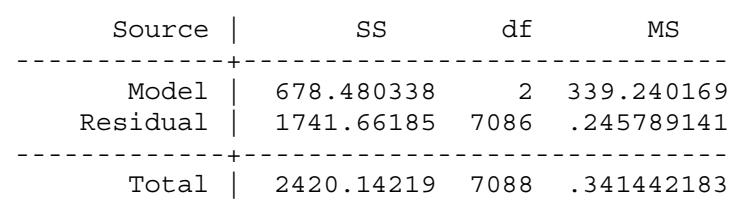

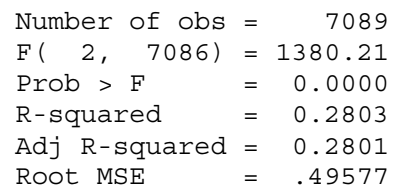

\begin{tabular}{|c|c|c|c|c|c|c|}
\hline $\ln W$ & Coef. & Std. Err. & $t$ & $P>|t|$ & {$[95 \%$ Conf } & Interval] \\
\hline & & & 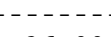 & & 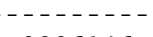 & $-2----$ \\
\hline xp & .0958324 & .0026617 & 36.00 & 0.000 & .0906146 & .101 \\
\hline sqpexp & -.0024115 & .0001008 & -23.93 & 0.000 & -.002609 & - . \\
\hline _cons & 9.796686 & .0126202 & 776.27 & 0.000 & 9.771947 & 9.82142 \\
\hline
\end{tabular}

Figure 8: Results, ordinary least squares regression, business school graduates, 1970census.

\begin{tabular}{|c|c|c|c|c|c|c|}
\hline Source | & SS & $d f$ & MS & & Number of obs & 2269 \\
\hline----------+ & --------- & -------- & ---- & & $F(2$, & 540.54 \\
\hline Model & 263.700785 & 131 & 850392 & & Prob > F & 0.0000 \\
\hline Residual & 552.728836 & 2266 & 922699 & & R-squared & 0.3230 \\
\hline--------+ & -------- & --------- & ----- & & Adj R-squared & 0.3224 \\
\hline Total | & 816.429621 & 2268 & 977787 & & Root MSE & .49389 \\
\hline & 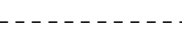 & 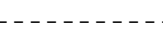 & & & - & -- \\
\hline $\ln W$ & Coef. & Std. Err. & t & $P>|t|$ & [95\% Conf. & Interval] \\
\hline - & --------- & ------- & ------- & ----- & ---- & ----- \\
\hline pexp & .0999329 & .0043521 & 22.96 & 0.000 & .0913984 & .1084674 \\
\hline sqpexp & -.0025426 & .0001625 & -15.64 & 0.000 & -.0028613 & -.0022238 \\
\hline _cons & 10.22356 & .0222558 & 459.37 & 0.000 & 10.17992 & 10.26721 \\
\hline
\end{tabular}

Figure 9: Results, random effects regression, teachers, earnings register.

\begin{tabular}{|c|c|c|c|c|}
\hline Random-effects & GLS regression & & Number of obs & 50153 \\
\hline Group variable & (i) : pid & & Number of groups & 1805 \\
\hline within & $=0.2680$ & & Obs per group: min & $=$ \\
\hline between & $=0.0206$ & & avg & 27.8 \\
\hline overall & $=0.2021$ & & $\max$ & 33 \\
\hline Random effects & u_i $\sim$ Gaussian & & Wald chi2(2) & 17749.49 \\
\hline $\operatorname{corr}\left(u_{-} i, \quad x\right)$ & $=0 \quad($ assumed $)$ & & Prob > chi2 & 0.0000 \\
\hline $\ln W$ & Std. Err. & $z$ & [95\% Conf & E. Interval] \\
\hline 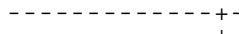 & --------- & -- & ------ & --------- \\
\hline pexp & .0783991 & 98.34 & .0768365 & .0799617 \\
\hline sqpexp & -.0018876 & -73.24 & -.0019382 & -.0018371 \\
\hline _cons & 9.94585 & 1255.63 & 9.930326 & 9.961375 \\
\hline----- & - - - - - - - - - - - - - - - - & --- & $\ldots$ & --------- \\
\hline sigma_u & .25123219 & & & \\
\hline sigma_e & .357633 & & & \\
\hline rho & .33042589 & of vari & due & \\
\hline
\end{tabular}


Figure 10: Results, random effects regression, business school graduates, earnings register.

\begin{tabular}{|c|c|c|c|c|}
\hline Random-effects & GLS regression & & Number of obs & 13110 \\
\hline Group variable & (i) : pid & & Number of groups & 465 \\
\hline within & $=0.3778$ & & Obs per group: min & 13 \\
\hline between & $=0.0593$ & & avg & 28.2 \\
\hline overall & $=0.3069$ & & $\max$ & 30 \\
\hline Random effects & u_i $\sim$ Gaussian & & Wald chi2(2) & 7694.71 \\
\hline $\operatorname{corr}\left(u_{-} i, x\right)$ & $=0 \quad$ (assumed $)$ & & Prob > chi2 & 0.0000 \\
\hline $\ln w$ & Std. Err. & $z$ & {$[95 \%$ Conf } & [. Interval] \\
\hline 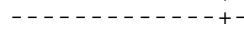 & ----------------------- & ------ & ---------- & --------- \\
\hline pexp & .0020061 & 59.45 & .1153397 & .1232035 \\
\hline sqpexp & -.0027991 & -40.75 & -.0029337 & -.0026645 \\
\hline _cons & .0185267 & 549.28 & 10.14014 & 10.21276 \\
\hline & -------------------- & & 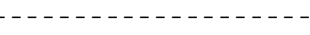 & --------- \\
\hline sigma_u & .29900569 & & & \\
\hline sigma_e & .4930236 & & & \\
\hline rho & .26890429 & of var & u_i) & \\
\hline
\end{tabular}

